\title{
Penerapan Strategi Pembelajaran Inkuiri Sosial untuk Meningkatkan Hasil Belajar IPS Pada Siswa Kelas IV SDN 84 Kota Pare-pare
}

\author{
Amir Pada \\ PGSD, Fakultas Ilmu Pendidikan, Universitas Negeri Makassar \\ amirpadda30@gmail.com
}

\begin{abstract}
ABSTRAK
Penelitian ini bertujuan untuk mengetahui Penerapan Strategi Pembelajaran Inkuiri Sosial dapat Meningkatkan Hasil Belajar IPS Siswa. Jenis penelitian adalah Penelitian Tindakan Kelas (Classroom Action Research) dengan prosedur tindakan: Planning, Action, Observation dan Reflektion. Pendekatan yang digunakan adalah pendekatan kualitatif. Populasi penelitian adalah seluruh siswa Sekolah Dasar Negeri No.84 Kota Parepare, sedangkan sampel yang digunakan adalah kelas IV yang berjumlah 23 Orang, yang terdiri dari 10 orang laki-laki dan 13 orang perempuan. Fokus penelitian adalah Penerapan Strategi Pembelajaran Inkuiri Sosial dan Hasil Belajar belajar siswa pada mata pelajaran IPS. Teknik pengumpulan data dilakukan melalui; observasi, tes dan dokumentasi. Selanjutnya tehknik analisis data dengan menggunakan analisis data deskriptif kualitatif. Hasil penelitian menunjukkan bahwa hasil belajar siswa pada siklus I berada pada kategori cukup (C) sedangkan hasil belajar siswa pada siklus II mengalami perobahan atau peningkatan dengan kategori baik (B). Kesimpulan penelitian yaitu terjadi peningkatan hasil belajar siswa pada mata pelajaran IPS melalui penerapan strategi inkuiri sosial pada Sekolah Dasar Negeri No. 84 Kota Parepare.
\end{abstract}

Kata kunci: learning outcomes, social inquiry strategies and social studies

\section{ABSTRACT}

This study aims to determine the Implementation of Social Inquiry Learning Strategies cans Improve Student Social Learning achievements. This type of research is Classroom Action Research with the procedure of implementing actions: Planning, Action, Observation and Reflection. The approach used is a qualitative approach. The population was all students of State Elementary School No.84 Parepare City, while the sample used was class IV totaling 23 people, consisting of 10 men and 13 women. The focus of the study is the Implementation of Social Inquiry Learning Strategies and Student Learning achievements in social studies subjects. Data collection techniques carried out through; observation, test and documentation. Techniques in analyzing data using descriptive qualitative. The results showed that the learning achievements of students in the first cycle were in the sufficient category fair $(C)$ while the learning achievements of the students in the second cycle experienced changes or improvements in the good category $(B)$. The conclusion of the study is an increase in student learning achievements in social studies subjects through the application of social inquiry strategies in State Elementary School No. 84 Parepare.

Keywords: learning outcomes, social inquiry strategies and social studies.

\section{PENDAHULUAN}

Mengingat arah dan tujuan pendidikan sangat penting maka, diperlukan buah pemikiran yang cemerlang untuk mewujudkan konsep tersebut. Hasbullah (2005) menyatakan bahwa tujuan pendidikan memberikan arah, sebagai titik awal mencapai tujuan kehidupan lainnya. Pendidikan tidak hanya berlangsung di sekolah, tetapi juga di luar sekolah yaitu rumah, lingkungan bermain dan masyarakat. Oleh karena itu, pembelajaran harus terkait dengan kehidupan nyata siswa sehingga nantinya pengetahuan yang diperolehnya mampu diaplikasikan dalam kehidupan seharihari. Hal tersebut sejalan dengan pembelajaran yang diharapkan dalam Kurikulum Tingkat Satuan Pendidikan 2006.

Untuk mencapai tujuan tersebut maka dilaksanakan pendidikan dalam berbagai jenjang, sesuai dengan kurikulum nasional yang memuat berbagai mata pelajaran termasuk bidang studi IPS, mata pelaaran ini 
memiliki sasaran pemelajaran untuk mempersiapkan siswa memiliki kemampuan menjadi warga negara yang baik (good zitizenship).

Seiring dengan sasaran pembelajaran IPS terebbut, saat ini diperlukan penerapan strategi pembelajaran yang bermutu agar siswa dapat berkembang secara optimal sesuai dengan bakat, minat, dan kemampuan yang dimilikinya. Untuk mengembangkan kemampuan yang dimiliki siswa, maka proses belajar bengajar harus mengarah pada pengebangan minat atau kesenangan subek didik, sehingga siswa belajar dengan efektif dan menyenangkan. Muhaimin, et. al, (2009). Pembelajaran efektif terjadi jika siswa terlibat aktif dalam proses pembelajaran. Menurut Banks (Djanali, 2007 ) Pengajaran IPS pada abad 21 dirancang untuk mempersiapkan siswa agar mampu berpartisipasi di masyarakat secara efektif dan mampu memecahakan permasalahan sosial yang dialami di lingkungannya.

Kurikulum tingkat satuan pendidikan (2006 : 575) mengemukakan ruang lingkup mata pelajaran IPS meliputi aspek-aspek sebagai berikut :(1) manusia tempat dan lingkungannya (2) waktu keberlanjutan dan perubahan (3) sistem sosial dan budaya (4) perilaku ekonomi dan kesejahteraan. Keempat aspek tersebut sangat penting diajarkan pada siswa SD untuk mempersiapkan diri menghadapi era globalisasi.

Hasil analisis kebutuhan pelaksanaan penelitian diperoleh informasi dari guru-guru bahwa pelaksanaan pembelajaran yang dilakukan selama ini di SDN 84, belum maksimal mendorong minat siswa berpartisipasi aktif dalam mengkaji konsep IPS. Sehinggga berimplikasi terhadap perolehan hasil belajar masih rendah.

Selain itu, kegiatan lain yang dilakukan adalah mengambil dokumen tentang hasil belajar siswa, silabus pembelajaran, dan Kriteria Ketuntasan Minimal (KKM). Dari kegiatan tersebut, diperoleh data bahwa kemampuan belajar siswa terutama pada mata pelajaran Ilmu Pengetahuan Sosial masih rendah yakni hanya $34 \%$ dari 23 siswa mencapai Kriteria Ketuntasan Minimal (KKM) 70 .

Rendahnya hasil belajar siswa itu disinyalir dari berbagai aspek antara lain guru dan aspek siswa. Dari aspek guru diperoleh inormasi bahwa guru masih kurang memberi kesempatan kepada siswa mengelola pikirannya sendiri. Selain itu, Penggunaan media pembelajaran kurang representatif, dan Penggunaan metode pembelajaran yang monoton pada satu metode saja.

Dari aspek siswa diperoleh data bahwa siswa kurang aktif (pasif) dalam pembelajaran, karena fokus penyajian dengan ceramah yang mengakibatkan siswa hanya menjadi pendengar dan pencatat apa yang dijelaskan guru. Selain itu, Siswa kurang termotivasi untuk belajar karena kegiatan pembelajaran tidak membangkitkan minat siswa untuk belajar.

Mengacu pada penyebab permasalahan tersebut, maka salah satu upaya yang dapat dilakukan untuk meningkatkan hasil belajar siswa pada mata pelajaran IPS adalah penerapan strategi pembelajaran inkuiri sosial. Strategi pembelajaran inkuiri sosial termasuk strategi yang modern, dan sangat didambakan untuk dilaksanakan di sekolah. Nursid (2000) berasumsi bahwa sekolah bisa menciptakan kultur bisu dan pasif, namun penoena ini tidak terjadi apabila strategi pembelajaran inkuiri sosial diterapkan dengan efektif, argumen ini dikemukakan karena strategi tersebut menempatkan siswa lebih banyak belajar sendiri dan menemukan sendiri, mengembangkan konsep serta kreatif dalam memecahkan masalah yang terjadi dilingkungannya. Pembelajaran dengan penggunaan strategi inkuir, siswa betul-betul ditempatkan sebagai subjek belajar sehingga nuansa pembelajaran mengarah kepola belajar mandiri. Peranan guru dalam strategi inkuiri sosial adalah pembimbing dan fasilitator dalam belajar.

Inkuiri sosial, menurut Sardijoyo (2008), Somantri, (2001) menjelaskan bahwa inkuiri sosial merupakan salah satu strategi pembelajaran yang berlandaskan pendekatan sosial. Strategi ini melibatkan siswa mencari data dan fakta yang berhubungan dengan materi dan masalah-masalah sosial di lingkungan sekitarnya.

Pemilihan Strategi pembelajaran inkuiri sosial untuk memecahkan masalah dalam pembelajaran soaial sangat cocok karena menurut Nasution (2013:81) bahwa: a). Strategi ini khusus dirancang untuk meningkatkan kemampuan dan keterampilan siswa dalam menemukan konsep atau masalah-masalah sosial, b). Beberapa hasil penelitian menunjukkan bahwa strategi ini terbukti efektif meningkatkan kemampuan dan keterampilan siswa dalam memecahkan masalah-masalah sosial, c). Strategi ini merupakan sinkronisasi antara teori mengajar 
dan teori belajar, yang memiliki prosedur yang sistematis dan mudah diterapkan oleh pengajar.

Berdasarkan analisis kebutuhan tersebut, maka penulis berupaya melakukan suatu perbaikan melalui penelitian ini dengan menerapan strategi pembelajaran inkuiri sosial untuk meningkatkan hasil belajar IPS pada siswa kelas IV SDN 84 Parepare.

\section{Strategi Pembelajaran Inkuiri}

Strategi pembelajaran inkuiri sosial menurut Sund (Trianto, 2007:135) bahwa inkuiri sosial sebgai suatu proses umum yang dilakukan manusia untuk mencari atau mamahami informasi. Druckman, D (2005) Strategi pembelajaran inkuiri sosial adalah rangkaian kegiatan pembelajaran yang menekankan pada proses berpikir secara kritis dan analisis untuk mencari dan menemukan sendiri jawaban dari suatu masalah yang dipertanyakan. Bobbi (2009) menjelaskan bahwa inkuiri sosial secara bertahap dapat meningkatkan kemampuan kritis siswa terhadap suatu masalah yang dipecahkan.

Penerapan strategi inkuiri sosial dalam pembelajaran IPS tetap mengacu pada prinsipprinsip yang sudah ditentukan. Dwyer (1978) mengemukakan bahwa prinsip-prinsip inkuiri yakni: prinsip intelektual, interaksi, bertanya, belajar berpikir dan keterbukaan. Wena (2009), mengemukakan langkah-langkah penerapan strategi inkuiri sosial yakni: 1) tahap orentasi, 2) tahap hipoteis 3) tahap definisi, 4) tahap eksplorasi, 5) Pegumpulan data dan 6) tahap generalisasi.

Kesimpuan dari beberapa pendapat maka sasaran strategi inkuiri sosial adalah agar: 1) siswa memiliki ketrampilan mencari konsep dan masalah sosial di sekitarnya, 2) siswa memiliki kemampuan dasar memecahkan masalah dan 3) memiliki ketrampilan dasar menerapkan konsep ilmu sosial dalam kehidupannya.

\section{Pendidikan IPS}

Istilah IPS sebagai bagian dari mata pelajaran yang diajarkan di jenjang pendidikan Sekolah Dasar telah dituangkan dalam kurikulum sekolah dimulai sejak tahun 1969, namun secara resmi di ajarkan pada tahun 1975 (Kurikulum 1975 ). Nu'man (1998) mendefinisikan bahwa IPS adalah mata pelajaran di sekolah dasar, dimana materinya bersumber dari berbagai disiplin ilmu-ilmu sosial dan humaniora yang disederhanakan dan diorganisi serta diajarkan secara psikologis dan pedagogik untuk tujuan pemdidikan di sekolah dasar.

Mata pelajaran IPS merupakan mata pelajaran integrasi dari mata pelajaran ilmu sosial seperti Sejarah, Geografi, Ekonomi, Antropologi, Sosiologi, Psikologogi sosial serta Politik Suradisastra (199). Menurut Somantri, (2001:74) Pendidikan IPS di Indonesia adalah penyederhanaan disiplin ilmu-ilmu sosial dan segala sesuatu yang sifatnya sosial yang diorganisasikan secara ilmiah dan psikologis untuk mencapai tujuan pendidikan nasional. Winatapurta (1992: 23) mengemukakan pendidikan IPS sebagai mata pelajaran di tingkat sekolah dasar pada hakikatnya juga merupakan suatu integrasi utuh dari disiplin ilmu-ilmu sosial dan disiplin ilmu lain yang relevan untuk merealisasikan tujuan pendidikan di tingkat persekolahan

Berdasarkan uraian di atas, dapat disimpulkan bahwa IPS merupakan studi terintegrasi dari ilmu-ilmu sosial dan humaniora untuk membentuk warganegara yang baik, mampu memahami dan menganalisis kondisi dan masalah sosial serta mampu memecahkan masalah sosial kemasyarakatan. Mata pelajaran IPS di sekolah merupakan sebuah studi dimana materi terkoordinasi secara sistematis dan dikembangkan atas dasar disiplin-disiplin ilmu-ilmu sosial, maka tujuan IPS adalah agar siswa memiliki pengetahuan, sikap dan ketrampian dasar berbangsa dan bernegara.

\section{Penerapan strategi inkuiri sosial pada pembelajaran IPS}

Implementasi langkah-langkah penerapan model inkuiri sosial pada pembelajaran IPS dilakukan melalui tiga tahap pemelajaran yakni: a) kegiatan awal, guru menyampaikan tujuan pembelajaran yang ingin dicapai. b) kegiatan inti, guru memberi informasi tentang permasalahan, siswa mengemukakan dugaan sementara mengenai masalah, siswa mencari kebenaran jawaban yang disampaikan, siswa mendiskusikan hasil temuan secara berkelompok, selanjutnya siswa melaporkan hasil temuan tiap kelopok di depan kelas secara bergantian. Guru memberi penguatan terhadap hasil kerja kelompok. 3) kegiatan akhir yakni mengadakan tindak lanjut dan melakukan evaluasi untuk mengukur keberhasilan belajar.

\section{Hasil Belajar}

Hasil belajar merupakan perubahan perilaku yang diperoleh pebelajar setelah 
mengalami aktivitas belajar. Untuk mengukur hasil belajar harus sesuai dengan tujuan pencapaian kognitif, afektif, dan psikomotorik yang disesuaikan dengan kemampuan siswa. Menurut Ali (2002) mengungkapkan bahwa "hasil belajar berupa perubahan perilaku, baik yang menyangkut kognitif, afektif, dan psikomotorik". Menurut Winkel (1989:82) hasil belajar adalah keberhasilan yang dicapai oleh siswa, yakni prestasi belajar siswa di sekolah yang di wujudkan dalam bentuk angka atau bukti keberhasilan yang telah dicapai.

Menurut Winarno (1980:25) menjelaskan bahwa hasil belajar bagi kebanyakan orang atau hasil ulangan dapat digunakan untuk menentukan indek dan keberhasilan siswa. Indek keberhasilan diperoleh dengan menggunakan beberapa jenis instrumen, salah satunya adalah soal-soal pilihan ganda ( PG ). Kelebihan jenis penilaian ini adalah mampu mengakoodasi/ mengukur seluruh materi yang diajarkan. Kerena itu melalui penelitian dengan menerapkan strategi inkuiri dalam pembelajaran IPS digunakan instruen tes pilihan ganda ( $\mathrm{PG}$ ), dengan harapan dapat merekam penguasaan siswa terhadap materi yang dipelajari secara keseluruhan.

Hasil belajar yang dicapai oleh siswa tersebut menjadi indikator untuk mengetahui kemampuan, kesanggupan, penguasaan pengetahuan tiap siswa. Suryanto (2009) berpendapat bahwa "hasil belajar adalah segala sesuatu yang menjadi milik siswa sebagai akibat dari kegiatan belajar yang dilakukannya".

Ada dua faktor yang mempengaruhi hasil belajar yaitu : a) faktor internal mencakup kondisi fisik seperti kesehatan organ tubuh, kondisi psikis seperti kemampuan intelektual, emosional dan kondisi sosial, yang meliputi kemampuan bersosialisasi dengan lingkungan. b) faktor eksternal adalah faktor dari luar yang mepengaruhi kondidi belajar seperti, tempat belajar, iklim, suasana lingkungan dan budaya belajar masyarakat. Nuansa belajar yang diharapkan pada penerapan strategi inkuiri sosal adalah terciptanya iklim dan budaya belajar yang kondusif dan menyenangkan.

\section{METODE PENELITIAN}

Penelitian ini menggunakan pendekatan deskriptif kualitatif. Adapun Jenis penelitian ini adalah penelitian tindakan kelas dengan daur ulang siklus. Apabila siklus pertama gagal akan di adakan perbaikan dengan melaksanakan siklus berikutnya. Arikunto (2006:91), Daryanto (2011) mengemukakan bahwa Penelitian tindakan kelas adalah suatu pencermatan terhadap kegiatan yang sengaja dimunculkan dan terjadi dalam sebuah kelas. Fokus penelitian ini adalah Proses pelaksanaan strategi pembelajaran inkuiri sosial dan hasil belajar siswa setelah tes akhir yang menggunakan strategi pembelajaran inkuiri sosial.

Subjek dalam penelitian ini adalah guru dan siswa kelas IV SDN 84, tahun pelajaran 2018-2019. Penelitian dilakukan secara kolaboratif dengan guru kelas. Jumlah siswa dalam kelas IV sebanyak 23 orang, terdiri dari 10 orang laki-laki dan 13 orang perempuan. Penelitian ini dilakukan dalam dua siklus dengan mengikuti prosedur/ tahap pelaksanaan sebagai berikut: Perencanaan (Planning), pelaksanaan tindakan (Action), observasi (Observation) dan refleksi ( Refection). Teknik pengumpulan data yang digunakan dalam penelitian ini adalah observasi, tes dan dokumentasi.

Hasil penelitian selanutnya dianalisis dengan menggunakan teknik analisis data deskriptif kualitatif yang dikembangkan oleh Milles dan Hubberman (Emzir, 2010) yang terdiri dari tiga tahap kegiatan yakni: Reduksi data, Penyajian data dan Penarikan kesimpulan.

\section{HASIL \& PEMBAHASAN}

Penelitian tindakan ini berawal dari permasalahan rendahnya hasil belajar pada mata pelajaran IPS hal ini disebabkan karena, penggunaan strategi dalam pembelajaran IPS belum maksimal, metode yang diterapkan belum bervariasi dan tidak memberikan peluang pada siswa dalam mengkonstruksi pengetahuaan sendiri sehingga berdampak terhadap kualitas hasil belajar IPS. Data dokumen hasil belajar menunjukkan nilai IPS masih banyak di bawah KKM (75). Selain itu rancangan pembelajaran masih berpusat kepada guru, aktivitas siswa kurang dimaksimakan. Disisi lain pembelajaran IPS di sekolah dasar memerlukan pemilihan strategi yang mampu mendorong siswa terlibat aktif dalam proses pembelajaran di kelas.Untuk melihat secara jelas hasil belajar siswa sebelum dilakukan penelitian dapat dilihat dalam tabel berikut:

Tabel.1 Data nilai pra siklus I

\begin{tabular}{|c|c|c|c|c|}
\hline & umlah siswa & & Presentase & Rata-rata \\
\hline Tuntas & Belum tuntas & Tuntas & Belum tuntas & \\
\hline 5 & 18 & $21 \%$ & $79 \%$ & 62.04 \\
\hline
\end{tabular}


Berdasarkan tabel 1 diperoleh gambaran bahwa nilai-nilai rata siswa sebelum dilakukan penelitian adalah 62.04. Persentase siswa yang mendapatkan nilai diatas 75 hanya $21 \%$ atau 5 siswa dan yang mendapatkan nilai kurang dari 75 adalah $79 \%$ atau 18 siswa, artinya kurang dari seperdua jumlah siswa yang memenuhi kriteria ketuntasan minimal (KKM), kondisi ini memerukan perhatian untuk dipecahkan.

Gambaran hasil belajar siswa dengan menerapkan strategi inkuiri sosial pada pembelajaran IPS melalui penelitian ini adalah :

\section{Pelaksanaan Siklus pertama}

Hasil Pelaksanaan penelitian yang dilakukan pada pembelajaran siklus I, berdasarkan lembar observasi tentang kemampuan guru menggunakan strtegi inkuiri sosial adalah $66,66 \%$ dengan kategori cukup (C) atau belum mencapai indikator keberhasilan yaitu $>76 \%$. Sedangkan data hasil rekapitulasi pada lembar pengamatan aktivitas siswa, pada siklus I menunjukkan bahwa dari jumlah 23 siswa, ada 7 siswa berada pada kualifikasi cukup (C), 5 siswa berada pada kulifikasi baik (B), dan 11 siswa berada pada kulifikasi kurang (K). Sehingga secara keseluruhan hasil observasi siswa pada siklus 1 adalah $67,17 \%$ atau berada pada kualifikasi cukup (C) atau belum mencapai indikator keberhasilan yaitu $76 \%$, yang berarti pembelajaran dilanjutkan ke siklus berikutnya.

Sedangkan data hasil evaluasi belajar siswa pada mata pelajaran IPS siklus 1 dengan menerapkan strategi inkuri social menunjukkan rata-rata 73,47 . Berikut tabel hasil belajar siswa pada mata peajaran IPS pada siklus 1:

Tabel 2 Data hasil belajar siswa pada pembelajaran IPS siklus 1

\begin{tabular}{ccccc}
\hline No & Perolehan Nilai & Frekuensi Siswa & Kategoi & Persentase \\
\hline 1 & $76-100 \%$ & 12 & Baik & $52 \%$ \\
2 & $60-75 \%$ & 11 & Cukup & $48 \%$ \\
3 & $0-59 \%$ & 0 & Kurang & $0 \%$ \\
\hline & & & & \\
\hline & Jumlah & 23 & & $100 \%$
\end{tabular}

Berdasarkan tabel frekuensi hasil belajar siklus 1 di atas maka dapat dijelaskan bahwa dari 23 siswa kelas IV SDN. 84 Parepare yang terdiri dari 10 laki-laki dan 13 perempuan yang mengikuti tes tindakan, terdapat 12 siswa memperoleh nilai baik (76-
100\%), 11 siswa memperoleh nilai cukup (60$75 \%$ ), dan tidak ada siswa yang memperoleh nilai kurang (0 - 59\%). Dari hasil tersebut didapatkan nilai rata-rata siswa pada siklus I yaitu 73,47 jika dikonversi dengan kriteria keberhasian maka niai tersebut dikategorikan baik (B).

Data penelitian membuktikan bahwa ada peningkatan hasil belajar jika dibanding dengan kondisi hasil belajar pra tindakan, nilai siswa tersebut sudah mengalami perobahan namun belum mencapai sasaran indikator keberhasilan minimal yang ditetapkan oleh sekolah yakni $76 \%$. Berdasarkan hasil refleksi maka data keberhasilan penelitian dinyatakan belum berhasil, penyebabnya guru pada tahap eksporasi hanya menghimbau kepada siswa mencari konsep permasalahan sosial terbatas pada satu buku paket saja, sehingga siswa memperoleh pengetahuan kurang.Hasil refleksi tersebut menjadi acuan tindakan pada pelaksanaan pembelajaran ke siklus 2 .

2 Pelaksanaan Siklus II

Hasil Pengamatan terhadap aktivitas siswa, pada pertemuan siklus II berdasarkan langkah pembelajaran strategi inkuiri sosial melalui instruen lembar obserasi, secara keseluruhan menunjukkan bahwa hasil observasi siswa pada siklus II adalah 90,90\% atau berada pada kategori Baik (B) dan sudah mencapai indikator keberhasilan yaitu $76 \%$. Sedangkan data kemampuan guru menerapkan strategi inkuiri sosial yang diperoleh melalui instrumen lembar pengamatan kemampuan guru, setelah di korelasikan dengan kriteria keberhasilan pada Bab III, maka kemapuan guru menerapkan strategi pebelajaran berada pada kategori Baik, yang berarti seluruh komponen strategi ini dapat dilaksanakan dengan tepat.

Selanjutnya data hasil evaluasi belajar siswa setelah proses pelaksanaan tindakan siklus II diperoleh nilai rata-rata siswa yaitu 91,73, berikut tabel hasil belajar siswa pada pembelajaran IPS dengan menerapkan strategi inkuiri sosial pada siklus II:

Tabel 3. Hasil evaluasi belajar siswa pembelajaran IPS pada siklus II.

\begin{tabular}{ccccc}
\hline No & Perolehan Nilai & Frekuensi Siswa & Kategoni & Persentase \\
\hline 1 & $76-100 \%$ & 21 & Baik & $91 \%$ \\
2 & $60-75 \%$ & 2 & Cukup & $9 \%$ \\
3 & $0-59 \%$ & 0 & Kurang & $0 \%$ \\
\hline & Jumlah & 23 & & $100 \%$ \\
\hline
\end{tabular}


Berdasarkan tabel frekuensi hasil belajar siswa siklus II di atas maka dari 23 siswa terdapat 21 siswa yang memperoleh nilai baik (76-100\%), 2 siswa yang memperoleh nilai cukup (60-75\%), dan yang memperoleh nilai kurang (0-59\%) tidak ada siswa. Data tesebut membuktikan bahwa hasil belajar siswa pada sikus II mencapai $91 \%$ dengan kategori baik (B), yang berarti sudah mencapai target KKM 75. Dari data tersebut setelah dianalisis dan direfleksi di simpulkan bahwa penerapan strategi inkuiri sosial sudah dilakukan dengan baik sehingga penelitian harus dihentikan pada sikus ke dua. Dari data hasil belajar siswa tersebut membuktikan bahwa dengan menerapkan strategi inkuiri sosial pada pembelajaran IPS dapat meningkatkan hasil belajar siswa di SD.

Hasil belajar merupakan perubahan perilaku yang diperoleh pebelajar setelah mengalami aktivitas belajar. Untuk mengukur hasil belajar harus sesuai dengan tujuan pencapaian kognitif, afektif, dan psikomotorik yang disesuaikan dengan kemampuan siswa. Menurut Ali (2002) mengungkapkan bahwa hasil belajar berupa perubahan perilaku, baik yang menyangkut kognitif, afektif, dan psikomotorik. Menurut Winkel (1989:82) hasil belajar dalah keberhasilan yang dicapai oleh siswa, yakni prestasi belajar siswa di sekolah yang di wujudkan dalam bentuk angka. atau bukti keberhasilan yang telah dicapai.

Hasil belajar yang dicapai oleh siswa menjadi indikator untuk mengetahui kemampuan, kesanggupan, penguasaan terhadap pengetahuan yang diharapkan. Asep (2004) berpendapat bahwa hasil belajar adalah segala sesuatu yang menjadi milik siswa sebagai akibat dari kegiatan belajar. Namun peningkatan hasil belajar tersebut dipengaruhi oleh dua faktor yaitu: a) faktor internal mencakup kondisi psikis seperti kemampuan intelektual yang meliputi pengetahuan yang diserap siswa. Perolehan aspek pengetahuan terjadi pada kondisi emosional mampu bersosialisasi dengan lingkungan, mampu mengakses informasi / materi yang relevan dengan kebutuhan di masyarakat. b) faktor eksternal adalah faktor dari luar yang mepengaruhi kondidi belajar seperti, tempat belajar, iklim, suasana lingkungan dan budaya belajar masyarakat. Nuansa belajar yang diharapkan pada penerapan strategi inkuiri sosial adalah terciptanya iklim dan budaya belajar yang kondusif dan menyenangkan.

Keberhasilan pembelajaran dapat diukur dari tinggi rendahnya nilai hasil belajar siswa pada mata pelajaran tertentu. Melalui penelitian tindakan kelas yang dilaksanakan di SD. Negeri 84 Parepare dengan menerapkan strategi inkuir sosial diperoleh gambaran bahwa hasil dan aktivitas belajar siswa pada pebelajaran IPS dapat ditingkatkan. Data keaktifan siswa pada siklus pertama menunjukkan bahwa frekwensi keaktivan siswa dari satu siklus kesiklus berikutnya mengalami peningkatan, terjadinya peningkatan aktivitas siswa disebabkan karena guru mampu menerapkan langkah strategi inkuiri sosial dengan tepat. Indikator keampuan guru menerapkan seluruh langkah pembelajaran strategi inkuiri, Temuan ini didukung oleh pandangan Dewey (2009) yang menyatakan siswa cenderung aktif berinteraksi jika apa yang dikerjakan menarik.

Dwyer (1998) mengungkapkan bahwa daya serap terhadap pelajaran tinggi apabila fisik maupun emosional siswa terlibat dalam pembelajaran. Pembelajaran dengan menerapkan strategi inkuiri mempengaruhi daya ingat siswa yang tinggi terhadap materi pelajaran Banks (2001), Porter (2001) jika penerapan strategi pembelajaran diakukan dengan terstuktur berdasarkan alur langkah strategi pembelajaran yang ditetapkan.

Kondisi prestasi belajar siswa berdasarkan hasil tes siklus pertama pada pembelajaran IPS dengan menggunakan strategi inkuiri sosial tergolong Cukup. Temuan tersebut membuktikan bahwa pembelajaran belum mencapai kriteria ketuntasan belajar (KKM), sehingga pembelajaran perlu dilanjutkan ke siklus berikutnya, Kunandar (2008). Nilai siswa berdasarkan hasil tes pada pelaksanaan sikus ke dua mengalami peningkatan dengan kategori Baik, ini membuktikan bahwa ada peningkatan jika dianding dengan pembelajaran pada siklus sebelumnya. Menurut Daryanto, (2011) apabila pembelajaran sudah mencapai target KKM yang ditetapkan maka penelitian di hentikan. Temuan di atas didukung oleh penelitian Irmawati (2013) yang menyimpulkan bahwa terjadi peningkatan yang signifikan penggunaan strategi inkuiri sosial dengan hasil belajar siswa yakni hasil penelitian pada siklus pertama menunjukkan kategori Cukup selanjutnya pada pembelajaran sikus kedua hasil belajar siswa berada pada kategori Baik. Ini berarti bahwa pembelajaran IPS dengan menggunakan strategi Inkuiri Sosial dapat meningkatkan hasil belajar siswa di sekolah dasar negeri 79 di Kota Parepare. 


\section{KESIMPULAN \& SARAN}

Berdasarkan hasil pelaksanaan penelitian melalui penggunaan strategi inkuiri sosial, dalam pembelajaran yang dilakukan maka dapat disimpulan bahwa: Penggunaan strategi inkuiri sosial pada pembelajaran IPS dapat meningkatkan hasil belajar siswa di SD Negeri 84 Kota Parepare. saran untuk penelitian selanjutnya agar kiranya dapat mengembangkan penelitian ini menjadi penelitian dalam wilayah penelitian yang lebih luas.

\section{DAFTAR PUSTAKA}

Ali, M. 2002. Guru dalam Proses Belajar Mengajar. Bandung : Sinar Baru Algesido

Arikunto, Suharsimi. 2006. Penelitian Tindakan Kelas. Jakarta : Rineka Cipta

Banks. James Amorose. 1990. Teaching Strategis for Studies Inquiri Veluing and Decission Making. Ohio Amborose Acegg Jr. Kent State Uniersity.

Barr.RD. BarthJ.L. and Shermis.S.S. 1977 Difiniting the Social Studies. Washinton DC Nasiona Council for the Social Studies.

Daryanto. 2011. Penelitian Tindakan Kelas dan Penelitian Tindakan Sekolah. Yogyakarta : Gava Media

De Porter, Bobbi, dan Hernacki, Milk. 2001. Quantum Learning. Diterjemahkan Oleh Alwiyah Adurrahman. Bandung: Kaifa PT Mizan Pustaka.

Dewey, John.C. 2013 Intersest end effort In Education. Boston Houghton, MC Millan.

Druckman, D. 2005. Doing Research: Methods of inquiry for conflict analisis. Oaks/California: Sage Publikation.

Dwyer Francis M., 1978 Strategis for

Improving Visual Learning, State College, Pensylvania : Learning Services.

Emzir. 2010. Metodologi Penelitian Kualitatif: Analisis Data. Jakarta: Rajawali Pers.

Hasbullah. 2005. Dasar-dasar ilmu pengetahuan. Jakarta: PT Raja Grafindo Persada

Kunandar. 2008. Penelitian Tindakan kelas. Jakarta: Raja Grafindo Persada.

Kurikulum tingkat satuan pendidikan (KTSP) tingkat SD/MI. 2006 . Jakarta : Depdiknas.

Margono, S. 2007. Metodologi Penelitian Pendidikan. Jakarta: Rineka Cipta.
Muhaimin, et. al, (2009). Manajemen Pendidikan,Jakarta : Kencana,

Nasution, S. 2013. Berbagai Pendekatan dalam Proses Belajar dan Mengajar. Bumi Aksara.

Sardijoyo. dkk. 2009. Pendidikan IPS di SD. Jakarta : Universitas Terbuka

Somantri, M. N. 2001. Menggagas pembaharuan pendidikan IPS, Bdg. Remaja Rosdakarya,.

Sugiono. 2012. Metode Penelitian Kuantitatif Kualitatif dan $R \& B$. Alfabeta.

Sumaatmadja, Nursid ( 2008). Studi Social, Bandung, Alami.

Suradisastra, dkk. 1993. Pendidikan IPS II. Depdikbud Dikti.

Suryanto, Adi. 2009. Evaluasi Pembelajaran di SD. Jakarta: Universitas Terbuka.

Wena, Made. 2009. Strategi Pembelajaran Inovatif Kontemporer. Jakarta : Bumi Aksara

Winaputra. 1992. Pembelajaran IPS SD. Jakarta : Depdiknas.

Winkel.W.S. 2007. Psikologi Pengajaran Yogyakarta. Media Abadi 